\title{
The Role of Single Parent Families in Adolescent Substance Addiction: Indian Perspective
}

\author{
Anuj Khandelwal ${ }^{1}$, Sonal Khandelwal ${ }^{2}$, Ashwin Jhalani ${ }^{3}$, Sheetal Bidkar ${ }^{4}$, Avinash De Sousa ${ }^{5}$ \\ ${ }^{1}$ Consultant Psychiatrist, Kiran Multi Super Speciality Hospital and Research Centre, Surat \\ ${ }^{2}$ Consultant Psychiatrist, Private Practice, Surat. \\ ${ }^{3}$ Resident Doctor, Department of Psychiatry, MGM Hospital and Medical College, Navi Mumbai \\ ${ }^{4}$ Clinical Psychologist, Suasth One Step Clinic, Mumbai \\ ${ }^{5}$ Consultant Psychiatrist and Founder Trustee, Desousa Foundation, Mumbai \\ E-mail-drajkl@yahoo.com \\ Corresponding author - Dr. Anuj Khandelwal
}

\begin{abstract}
Introduction: Among the many epidemic problems which India is fighting today, two very important social epidemics worth exploration are the issues of Adverse Childhood Experiences (ACEs) (in reference to parent-child relationship, divorce \& single parenting) \& substance use among adolescents. Worldwide there is an enormous amount of literature on these issues and their shared interactions, but in Indian context we find ourselves far behind with just sparse amount of literature on the same.

Methodology: A qualitative exploratory model is used for retrospective study of clinical cases of alcohol/ substance use in children/ adolescents of single parent family who visited a Deaddiction-RehabilitationCounselling Center in Andhra Pradesh for treatment during the period from January 2014 till July 2016. The cases are identified and studied considering review literature on the topic.

Conclusion: This article reminds us about the importance of long preserved Indian culture where people had immense respect for the sacrosanct union \& sanctity of marriage. We need to return back to our sacred ancestral ideologies so as to preserve a world where our kids are not drug driven but have actually moral base to their decisions in life. We can dream of a world without drug abuse only if our family environment is healthy with immense social support for our next generation.
\end{abstract}

Key Words: adolescent substance abuse, adverse childhood experiences, parenting.

(Paper received $-12^{\text {th }}$ May 2017, Peer review completed $-10^{\text {th }}$ June 2017 , Accepted $-12^{\text {th }}$ June 2017)

\section{INTRODUCTION}

Adverse childhood experiences (ACEs) are closely linked to dysfunctional family environment and thus what seems prudent to understand first is the family functioning. Family forms the fundamental unit of any society and thus its individual characteristics influence the acquisition of moral values, rules and roles by a person. Moreover, a family unit is the medium to pass on the spiritual and cultural heritage of society to the individual [1]. To study the various family aspects researchers most commonly use 'The General Systems Theory' [2-4] which when applied to families, views family as a constellation of shared memories $\&$ relationships, aspirations, successes and failures [5]. It views family as a complex system composed of several components or subsystems, namely parental subsystem, parent-child subsystems and sibling subsystems. Many authors go further by making a distinction even between the marital and the co-parental subsystem [6-8]. It gets more complex when the General Systems Theory is applied to post-divorce families, as these are characterized by more number of subsystems [9]. But when it comes to the Indian context, rate of remarriages or cohabitation is quite low and thus it seems valid to consider that the children in post-divorce families in India mainly belong to single parent family and do not come across 
more family relationships when compared to the intact families. All the subsystems in a family are interlinked such that a change in one causes a change in the rest [10-11]. Therefore parental divorce and growing up in a post-divorce family has huge impact on the child. The child is exposed to a greater number of risk factors for negative developmental outcomes [12-17]. Thus, to get insight about the child functioning and behavior in an intact family or post-divorce in a single parent family, we need to examine the entire family system and its component subsystems [18-19].

Associations among the various family subsystems can be viewed by either the spillover perspective or the compensatory perspective [20]. Most of the studies in literature support the use of spillover perspective to study the family dynamics [20-21]. Spillover perspective advocates the spill of emotions and behavior from one family subsystem into other subsystems. Thus, all the subsystems in a family are connected and interlinked in such a way that any change in one produces changes elsewhere. This is evident in the available literature which advocates a strong link between the quality of family relationships and psychosocial adjustment of children [22-24]. Parent child relationship quality and connectedness affects psychosocial adjustment of children which in turn influences substance use in a child or an adolescent [2528]. Given the social pressure to have alcohol the issue becomes even more salient as parents and the adolescents themselves may wish independent decision making and self-determination, but unsupported and non-guided adolescent decision making could lead the adolescent down the slippery slope of addiction and worsen his wellbeing [29]. In a prospective study of 5 years' duration from 2000 till 2005 in postprimary school students McCann et al studied the associations between parental control, parent-child attachment and parental solicitation on adolescent alcohol use. The study results clearly indicated a strong inverse relationship between parental control and adolescent alcohol drinking behavior, wherein a greater parental control was associated with less frequent adolescent alcohol drinking. Contrary to most studies they found only a little influence of parent-child attachment and parental solicitation on alcohol use [30]. Also noteworthy fact is the correlation between substance use in parents and the potential child harm by intoxicated parents [31].

\section{Single Parent Family v/s Intact Family}

So, the importance of parent-child relationship and parental control in regard to adolescent's problem behavior or adolescent's problem drinking is quite evident. This gets even more obvious and visible when an intact family situation is compared to single parent family. In a study in Netherland, a significantly less problem behavior was noted in children of 88 intact families when compared with those of 50 divorced single mother families [32]. Similar finding has been replicated in many other studies in literature [33-34] and thus it warrants a greater focus on single parent families in the society. The problem looks even bigger when we consider the divorce statistics over the past few decades which clearly show an upsurge in the rates of divorce all over the globe and thus there is a considerable change in the concept of "family" today. With a rise in divorce rate, there is also a rise in single parent families and thus it forms an important aspect of social change which is worth exploring. Divorce and marital separation are among the most stressful life events when calibrated on Social Readjustment Rating Scale (a widely used measurement tool for life events causing stress) [35-36]. This is because apart from the catastrophic acute impact of separation, there are many long lasting stressors associated with the event which include ongoing conflicts between ex-partners \& financial problems [37-38]. Also a high amount of parental stress is observed in a single parent family because the absence of one parent marks lack of emotional support, lack of assistance in child rearing, lack of sharing of day to day responsibilities and presence of stresses associated with raising a child [39-40]. Inherent to high parenting stress in a single parent family are lower quality of the family relationships, less adaptive parenting behavior, and adjustment problems in children [41-44].Thus divorce or marital separation cannot be viewed just as a single negative event for a family, rather is a chronic series of such negative events taking a huge toll on each subsystem in the family. It negatively affects the post-divorce adjustment of children not only because of it being a major stressful life event for them but also by the associated chronic stressors [45-49]. For sure separation from one parent is detrimental but if separation involves both the parents than it gets even more devastating for the child [50].

\section{Childhood/ Adolescence: Crucial in a person's life}


Stress inherent to relationship dissolution marks the difference between the child upbringing in an intact family or a post-divorce family [51]. But whether we consider an intact family or a single parent family, childhood and adolescence are always the most crucial periods for healthy physical and mental outcomes later in life [52-56]. It is when these naïve adolescent brains for the first time negotiate through difficult social, cognitive and emotional challenges in life. Thus, guidance and support from parents along with a healthy supportive family environment is a must for youth to live these difficult times [57].

\section{ACEs and Alcohol/ Substance Use}

A dysfunctional family environment or Adverse Childhood Experiences (ACEs) interferes with the ability of adolescents to cope in a better way with these difficult times of life and makes them feel insecure, lonely, with lack of power or control. These children face difficulty in finding their place in society and thus suffer either with internalizing disorders like anxiety disorder/ depressive disorder or externalizing disorders like oppositional or conduct problems [58]. Studies suggest that ACEs or childhood trauma changes the trajectory of the brain development by epigenetic mechanisms. These mechanisms cause a change in gene expression and thus a change in structure and function of brain, neuroendocrine, autonomic and immune functions of an individual, thus influencing the way an individual respond to stress [59-61]. Not only the biological response to the stressors is affected, ACEs also increases the probability of an adolescence or an adult to engage self in health-risk behaviors [62-63] because it adversely affects the person's coping skills and emotional functioning [64-65]. Thus the traumatized children during stressful life events leave the interpersonal frame for emotional regulation and move towards substance use which provides a quick fix for the stress.

Also noteworthy is the theoretical construct of shame which play central role in establishing the vicious circle of substance addictions. Substance use develops as a maladaptive \& misguided style of coping with unwanted negative emotions, such as shame, anger \& loneliness. Drugs and/or alcohol help adolescents to make these distressing emotions feel more distant, but not for long enough time, rather what often ensues is a destructive vicious cycle of shame/anger \& substance addiction. The person drinks to escape shame but unfortunately finds self in even more shame because he has been drinking out of control. This cycle keeps on repeating \& causes great harm to the person \& society [66-70].

Thus, ACEs particularly at the middle school years are quite risky as it is at this period when substance use may culminate and rapidly develop into a firmly rooted problem. Another noteworthy point in this age group children is that they begin to have more affiliation for peers than their families, and receive less supervision and monitoring from their parents [71]. There are many risk factors responsible for adolescent or adult substance use but among all, childhood life experiences play the key role and thus deserve exploration [72-76].

The ACEs include family dysfunction, multiple types of abuse (physical, sexual, and psychological), and neglect [77-78]. Divorce of parents, domestic violence, physical and sexual abuse, neglect, poor parentchild relationship, unstructured family and family history of drug addiction, all are associated with higher risk of alcohol and substance use [79-80]. Most adolescents continue with substance use into their adulthood and thus substance use in adolescence is a predictor of future substance related health problems in the society [81-82]. Furthermore, it leads to a high amount of interpersonal violence linked with social problems and economic problems [83].

\section{Single Parenthood in Indian Context}

Acknowledging the Indian culture with people having immense respect for sanctity of marriage and social ethics, it's not surprising to find the divorce rate in India ranking lowest throughout the world. But the noticeable aspect about the divorce rate in India is it's rise over the past decade, from 1 per 1000 Indian marriages to 13 per 1000 [84-85]. The increase in divorce rate is by 350 per cent in Kolkata for the period between 2003 and 2011, while almost a double increase in a 4-year span from 2010 till 2014 in Mumbai [86]. Statistics thus support the idea of substantial change in family life with more and more couples all over the country opting out of unhappy alliances. Now the people do not subscribe to the rigid notions of 
marriage or of it being a sacrosanct union [87]. No longer are women groaning under the fetters of the illusion of perpetuity of marriage. On the brighter side, we see an upshot in women getting employed and empowered to take charge of their life by filing petitions for dissolution of unhappy, abusive marriage. But the grim aspect of this change is that, now divorce is seen as an easy way out to escape the problems arising from marriage without any effort to save it. Thus, there is a rise in single parenthood in India which is a matter of serious concern. In a study of single mothers conducted in four metropolitan cities of India by Sundar et al. partner death accounted for most single parent families. The percentage share of partner death was $54 \%$, separated were $25 \%$, deserted or abandoned were $15 \%$ and only $6 \%$ were legally divorced [88]. Childhood parental loss by death, divorce or separation of parent differs at many preceding variables but all have in common the transition from a two parent to a single parent household [89].

\section{Single Parenthood and Alcohol/ Substance Use in Children/ Adolescents of India}

Parental loss by any means is a major ACE which predisposes a child or adolescent to a range of psychiatric disorders [90]. It acts as a powerful motivator and rocket fuel for the need to feel better or escape the reality. This is where substance use cons an adolescent by providing escape from reality and makes the pain look more distant. Alcohol and drugs provides with a sense of relief from pain of life and thus awards a temporary sense of peace, control, calmness [91]. Therefore, an alarming rate of increase in substance use in school going adolescents in India has been noted [92-93]. Also as India is estimated to have the largest child population and largest population of street children in the world [94], this issue of parent-child relationship, single parenting and adolescent substance use becomes more salient in Indian context.

The aim of this article is to review available literature on the psychological factors that are involved in divorce or separation and alcohol/ substance use by adolescents; and then to shed light on the importance of the same in Indian context. Thus, highlighting the importance of inclusion of psychological perspective to the treatment offered to children and adolescents of single parents having alcohol/ substance use in Indian scenario. To illustrate the central themes for therapy and clinical intervention we present 6 clinical cases of alcohol/ substance use in children/ adolescents of single parent family who visited Amrita Foundation Society's Deaddiction-Rehabilitation-Counselling Center, Secunderabad, Telangana, Andhra Pradesh for treatment during the period from January 2014 till July 2016.

\section{METHODOLOGY}

A qualitative exploratory model is used for retrospective study of clinical cases of alcohol/ substance use in children/ adolescents of single parent family who visited a Deaddiction-Rehabilitation-Counselling Center in Andhra Pradesh, for treatment during the period from January 2014 till July 2016. The cases are identified and studied considering review literature on the topic. During their visits in past the patients were evaluated and data was obtained and noted through a semi-structured interview by a psychiatrist and a psychologist as a part of their routine care. Also, the case history verifications were done from a reliable and adequate informant, generally a close family member. Concept Map tool was applied to study the already recorded clinical case data, as concept mapping forms not only a powerful tool for representing and archiving knowledge, but also to create new knowledge about the problem or issue in hand $[95,96]$. Concept map tool was thus utilized with hopes of opening opportunities for newer insights \& knowledge creation into the topic. Case study analyses, interviews and other similar techniques are for sure valuable in extracting and representing expert knowledge, but might still be best presented in the form of concept maps. This is because it not only represents the expert's knowledge, but also helps us find the gaps in the collected knowledge structure through interviews [97-98]. By this tool the knowledge is organized and represented in a graphical and hierarchical form such that the concepts are enclosed in boxes or circles and the line linking two concepts indicates the relationship between them [99]. Also, the most general concepts are placed at the start of the map and the more specific or less general concepts are arranged hierarchically at the end side. To be remembered is the fact that concept maps are not just graphic representation of 
information rather is truly a profound and powerful tool to procure new knowledge with profound meanings. Since long the researchers in various fields have been using concept map tool to create new knowledge, [99-102] and thus we decided to use it for evaluation of the cases for our study. We defined 'concept' as a meaningful knowledge pattern designated by a meaningful label seen in the available literature on substance use among adolescents in single parent family. Already recorded data having the detailed case history was reviewed and a meticulous concept mapping was done to highlight the relevant common variables and newer case findings if any with respect to the subject of study. Concept maps were utilized to graphically represent and analyze events in context of alcohol/ substance use among adolescents in single parent families. To assure reliability and welcome different perspectives, the clinical case data were independently assessed and analyzed by all the authors. The categorizations and concept maps were compared and the discrepancies were discussed. The final categorization and concept mapping was formed based on mutual agreement [103].

\section{CLINICAL CASES}

\section{Patient A (Figure 1)}

A 32yr old unmarried Muslim male was brought to the clinic after a road traffic accident under alcohol intoxication. After stabilization and detoxification treatment the patient was interviewed in detail for family dynamics and the concept map charting was done. Inter-religion marriage caused his parents a massive loss of social connectivity \& loneliness. Also, they had dysfunctional interactions between each other's family. All these factors contributed to his parent's frequent fights which many a time led to short time separations. The parent's dysfunctional thoughts, emotions and behaviors conveyed confabulating messages to the patient regarding religious beliefs \& socially acceptable behaviors. They relocated to Dubai but the problems continued. His parents finally got separated when the patient was 16 years old, the reason being his father's second marriage. Patient with his mother and 5 other siblings returned to India. Mother started supporting the family by singing in an orchestra group, but was never sufficient to run a family of seven members. Patient being the eldest among all siblings was looked upon by everyone as a helping hand and thus he dropped the dream of pursuing MBA as a career and started searching for a job. It was this time when he started with alcohol use along with some of the people in locality. Soon he joined a clerical job in some private company, but lost this job within a period of 4 months as was found alcohol intoxicated during the job hours. Later he did not apply for any other job, rather started consuming alcohol more frequently. Due to this his inter-personal relationship with other family members went on getting worse.

In alcohol intoxicated state the patient phone called his father and held him responsible for the family disturbances and misery. Within two weeks of this conversation his father expired of a heart attack and for this he held himself responsible. He also had the guilt of not been able to share the financial burden of his mother and sisters. There were role conflicts in the family and everyone was playing power games. Also, the father's property was not fully given to them, rather was divided among grandparents, his father's second wife and the patient's family. He was not happy and due to lack of appropriate coping skills went into more and more addiction for quick fixing his emotional disturbance. Anger on self, role conflicts, property issues lead to constant stress and unhappy environment at home which in turn contributed to his continuation of alcohol addiction.

\section{Patient B (Figure 2)}

A 28-year-old unmarried male patient was brought to the clinic for detoxification treatment. On detailed interview, it was noticed that the patient relapsed after a long 5 years' period of sobriety. He was born and brought up in taxes USA where at the age of 14 yrs. he experimented with marijuana smoking along with his friends. Later he started using marijuana on a more regular basis with his girlfriend who was already habitual of taking it. Within next one year patient started using other substances including stimulants like 
methamphetamine, cocaine \& opioids like brown sugar. He would be seen intoxicated for most of the time in a day and was seen to indulge in illegal activities. Because of his frequent involvement in illegal activities he got deported from USA to India at the age of 16 years. In India, he was given detoxification treatment, psychotherapy and group counseling sessions. During the recovery period, patient started working as a play group school teacher and started making amendments with his parents and family. $\mathrm{He}$ also stared pursuing new courses related to teaching industry. He maintained his sobriety for 5 years.

After a long 5 years' period of sobriety patient came to know about his mother who was fighting an incurable cancer and undergoing intensive treatment for the same. On one hand by legal norms the patient could not return to USA to see his mother, while on the other hand seeing the severity of the illness father did not want any change of hospital and treatment facilities. Thus, the patient experienced an extreme sense of helplessness and guilt because of his inability to visit his mother in the last days of her life. Family was busy in taking care of his mother and a minimal support was left for the client. Father tried to keep balance, but still the patient felt left out and depressed. He stopped going on regular treatment follow ups and meetings thinking about taking responsibility by self and of doing something significantly good before mother's death. He tried keeping himself busy to avoid the thoughts of helplessness and guilt, but eventually the detour method of handling early warning signs of relapse failed. With his mother's death, all the family members left for USA while the client was staying alone in India. Feelings of guilt, loneliness, helplessness, frustration \& grief of mother's death, all overpowered the patient and he eventually landed up in relapse.

\section{Patient C}

A 33-year-old unmarried male patient was brought forcefully to the clinic by his mother after giving a threat of withdrawing her financial support for his daily living. He lived with his mother who was supporting the family by running a small hair salon. His sister married two years back and got settled in USA. She also supported the family whenever financial crisis occurred. Client finished his M.B.A degree seven years ago but due to alcohol addiction he couldn't do any job for more than 2 to 3 months. Due to his alcohol use he would either lose his job because of excess work holidays or due to his work time alcohol use. His alcohol use started when he was 15 years old when for the first time he experimented with alcohol under peer pressure. Although he was genetically predisposed for addiction as his late father had alcohol use disorder and he died of alcohol liver disease when the patient was just 13 years old. His father was a chronic alcoholic and the patient never saw him functional. Although he was a constant troublemaker at home, the mother being codependent never took a stand against his alcoholism and behavior, rather she ignored both her children and supported the dysfunctional husband. Patient's father was very aggressive and many a times he had beaten up the mother till she bleeds. Since the time his father began to victimize the patient and the patient's sister of his aggressiveness in intoxicated state, the patient's mother shifted them to their maternal grandparent's place. Mother used to come every Sunday for two hours to meet the kids but was always seen preoccupied with her husband's thoughts and matters. Mother was trying to provide care to the kids both emotionally \& financially, while at the same time was bearing the violence of her alcoholic husband \& paying the debts made by him.

The patient reported that for him and his sister, it was an open secret that their father was an alcoholic. Patient reported about the embarrassment he and his sister underwent when they heard all their relatives, neighbors and even school teachers discussing their father's violent erratic behaviors and mother's irrational thoughts for supporting an alcoholic, disruptive and unconcerned husband. Mother always used to feed the concept of destiny and luck, while the father always took advantage of care \& commitment of mother for their marital relationship. The patient, his mother and his sister had to face a lot of criticism from relatives and friends for the father's behavior. As a child, the patient remembered his father telling him about alcohol being good and an ideal solution for all kind of problems and mother not objecting the idea. Thus, the patient received confabulating messages regarding the father's alcohol use and behavior. When client was 13 years of age, his father passed away and the paternal family refused to give their share in property. Mother filed a case against the in laws which was again a financial burden. Father being an 
alcoholic never really saved anything, rather the mother had to pay for his debts and the loan amount which he took long back against the current residence where they were living.

Thus, to share the financial burden the patient's sister started doing a part time job. Patient also did some short period jobs during his summer vacations but felt extremely helpless many a times when was not able to support enough. Some of the relatives advised him to quit his education and earn for the family but his mother and sister never allowed him to do so. As a child, he was afraid of his father, back at the grandparent's place he was anxious that the father might kill mother, and as an adolescent he felt extremely humiliated whenever came across any sort of discussion about his father. As an adult, he was having difficulty facing new people and was not able to introduce self. There was always a performance anxiety which troubled him. To cope up with these emotions and feel relaxed he started using alcohol and soon he became dependent on it. He reported guilt, self-criticism and extreme helplessness as contributors towards his alcohol relapses.

\section{Patient D (Figure 3)}

A 34-year-old male patient, a known case of alcohol use disorder came to the clinic after multiple past alcohol related relapses. His father was already using alcohol in dependence pattern when he for the firsttime started experimentation with alcohol along with his school friends at the age of 13 years. The first time he used alcohol was out of curiosity and later because of his pleasure-seeking personality traits. He soon within a period of 6 months started smoking nicotine cigarettes and chews tobacco in form of Ghutaka. Patient saw his mother nearly every day fighting with his father over alcohol use and his father abusing and beating her up. His father passed away because of alcohol liver disease, when the patient was just fifteen-year-old. As his father passed away he had to take over the family responsibilities at a very young age $\&$ had to face many difficult situations all alone. The patient joined his father's business to earn his living. He was diplomatic, extrovert, manipulative \& thus managed marketing for his business very nicely. He successfully took over the family responsibilities and managed to get his sister married. He took over the ancestral property related court case responsibility too but the family members were quite unhappy with his property related decisions. He had conflicts with his sister in regard with the ancestral property. He lacked coping skills to deal with the stressors in life, rather had a low frustration tolerance \& impulsivity, because of which he indulged more and more into alcohol use. Along with this, easy money through business \& lack of accountability further contributed him to reach the dependency level.

He got married at the age of 27 years to one of his classmate, but soon she discovered his alcohol dependency and thus divorced him within one year of marriage. He somehow managed second marriage but that too broke within a few months due to his alcohol use pattern. Both his wives won a heavy alimony from the case they filed against him. After all this he stood at the verge of bankruptcy when he realized the need for treatment and since past 6 years he underwent many detoxification treatments and relapses, but this was the first time when he was started on psychotherapy along with medications. He showed improvement during the treatment this time.

\section{Patient E (Figure 4)}

A 64-year-old unmarried Muslim male patient was brought to the clinic after he got his rib fractured during a fall in the bathroom under alcohol intoxication. He started living with the maternal family since the age of 9 years because of the separation of his parents on the issue of his father's second marriage. His maternal family shared his academics and other expenditures. Because he had a good understanding about the help and favors of the maternal family he always remained submissive and cooperative. He was a welladjusted child and never bothered others with his demands. He completed his education in Mumbai and during that period he made some close friends with whom he was emotionally close and used to spend time. Occasionally once in a month he used to have alcohol in his friend's company. Soon after completion of education he joined a travelling company as an accountant. Soon because of peer group pressure the patient started with a more often alcohol use. Noticing a change in the patient's regular behavior with disturbed biofunctions the family members discovered his alcohol taking behavior. Upon 
insistence by family the patient stopped alcohol use \& moved out of Mumbai to get away from his nonsober peer group which acted as a strong trigger for him to have alcohol. He shifted to Hyderabad and he started working as an employee in his cousin sister in law's back office. He remained absolutely sober for long 20yrs with the cold turkey method \& there were no complaints regarding his conduct there. During this period, he got into a love relationship with his colleague but she refused because of inter-religion issues. This along with his mother's failed marriage caused him the fear of dysfunctional relationship \& thus he decided to be single throughout his life. Family was always supportive and showed respect to his decision of not marrying.

Within some time of his breakup the patient visited Dubai for attending an official meeting. There he had alcohol and this marked his relapse. He continued with occasional alcohol use thereafter and soon he started drinking every day evenings. Over time due to the preoccupation with alcohol cravings the patient started wrapping up his work early. His aunt acknowledged a change in his biofunctions but the patient manipulated and decided to maintain more secrecy about his alcohol use. Soon he started hiding his morning drinks in the bathroom and cupboards. There were many episodes of pass outs and physical withdrawals but he continued with alcohol use because of alcohol cravings and painful loneliness. Fear for giving Commitment, Avoidance of Responsibility, Feeling of Guilt, Fear of Rejection, Fear of being Dependent were also contributing to his continued alcohol use. Fear of Dependency and painful loneliness was so much that at the age of 64yrs he was not ready to even think about his retirement plan.

\section{Patient F}

A 35 years old married male patient, pujari by occupation, hailing from low socio-economic strata of society came by self after an accident in alcohol intoxicated state. The patient had a good insight into his illness \& was in preparation phase of motivation for treatment. The patient's father passed away in a road traffic accident when patient was just 10 years old \& due to the father's sudden death, the patient's entire family had to face many problems. Patient's mother was illiterate and so it was difficult for her to feed the family. So they took shelter at the patient's grandparent's home. His grandparents and his maternal uncle humiliated \& took advantage of the patient, his mother and his sister by making them work for long hours and passing crooked statements on them. His grandfather would lecture him about his own greatness in giving them shelter and help. The patient would feel helpless \& miserable because of all these things and thus he started finishing more tasks then given to him by grandparents, but the situations never improved. He was brilliant in academics but because of grandfather's disapproval for further studies he had to drop out after passing 10th standard. Mother being submissive and dependent never really supported the patient for further studies. Grandfather forced the patient to work and would take away the major chunk of his earnings. Although the grandfather was a crooked person but he fulfilled his promise of marrying the patient's sister $\&$ also he promoted the patient to learn astrology to work as pujari. Because of all this the patient had a love-hate relationship with his grandfather.

To overcome the pain of life, frustration, anger and helplessness the patient started drinking beer every day at the age of 17 years. Still later by the age of 22 years he started using country made foreign liquor and in increased quantity and frequency. Grandfather used to verbally abuse the patient for his alcohol habit and the patient when in alcohol intoxicated state would confront him. The patient started working as Pujari for many bars and thus could manage alcohol every evening. By the age of 27 years the patient got completely alcohol dependent. Low self-esteem, rejection \& criticism from the apathetic grandfather, lack of education, frustration and helplessness were the contributing factors for continuous pain in life and thus alcohol use. Eventually the patient got married and after marriage he supported his wife for further education of school teacher. After his wife started working as teacher, she threatened the patient to divorce because of his alcohol use habit. She often confronted the patient for his alcohol use and related behaviors. The patient felt insecure as her threats would trigger the patient's past time memories of being dependent on maternal family. Even a couple of times wife took both the children and went to her father's house. This evoked anxiety \& fear in the patient, thinking about his son and daughter of undergoing the similar 
bad, neglected and humiliating treatment from their maternal family as the patient underwent from his in the past. Thus, he came for help and treatment of his alcohol addiction problem.

\section{Figure 1 - Qualitative analysis of Patient A}

Patient A

Inter religion marriage of parent
Parent's marital conflicts \&
Unhealthy parenting
Father's second marriage \&
Separation from father (Single
Parenting)
Migration from Dubai to India
Adjustment Issues
Sibling Rivalry
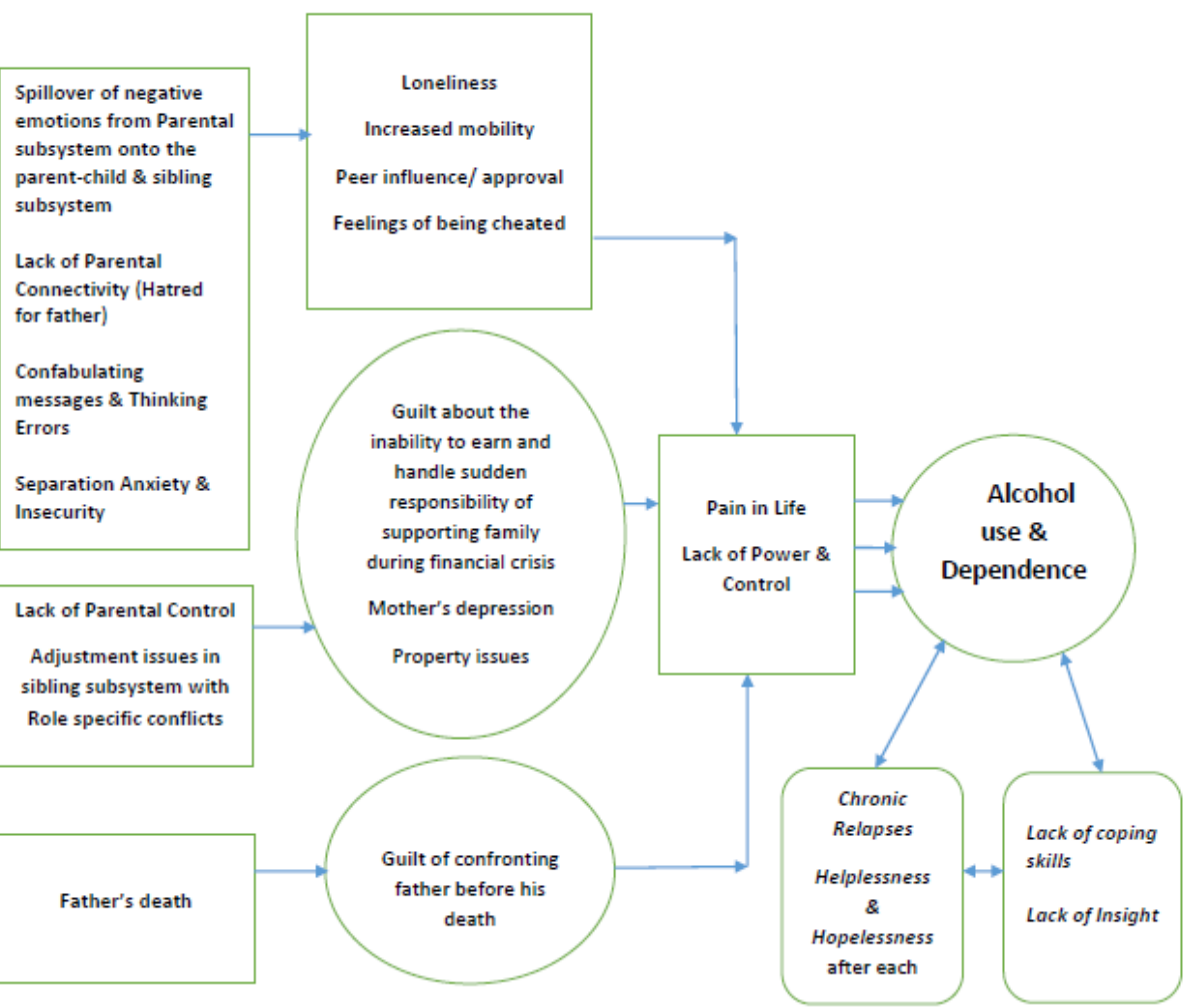

Figure 2 - Qualitative analysis of Patient B

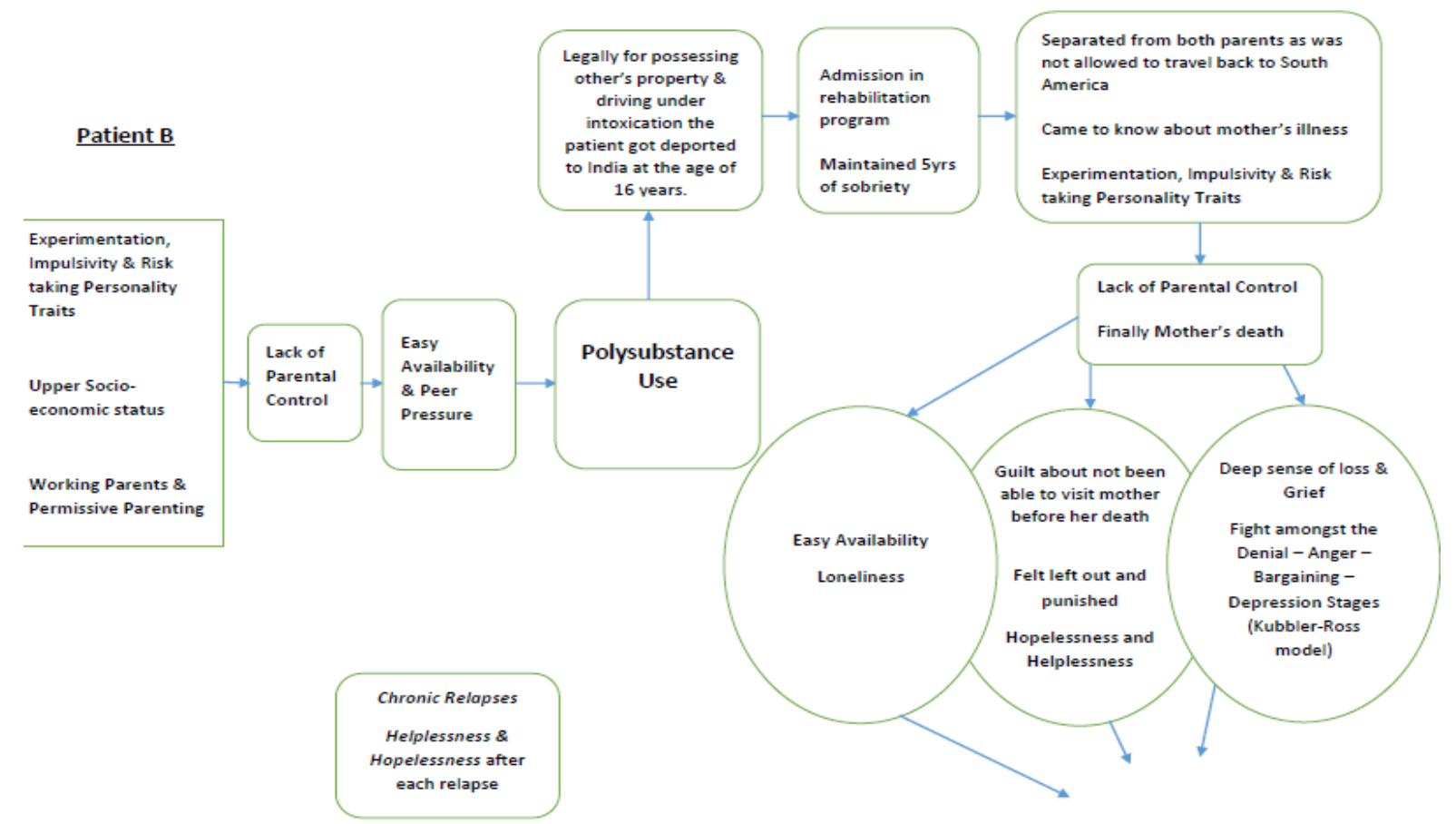

Polysubstance use with lack of coping skills 
Figure 3 - Qualitative Analysis of Patient D

\section{Patient D}

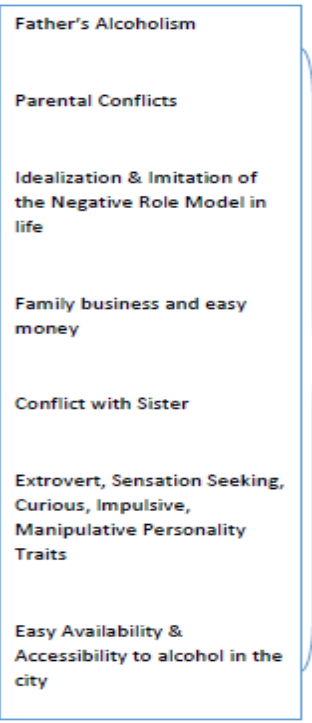

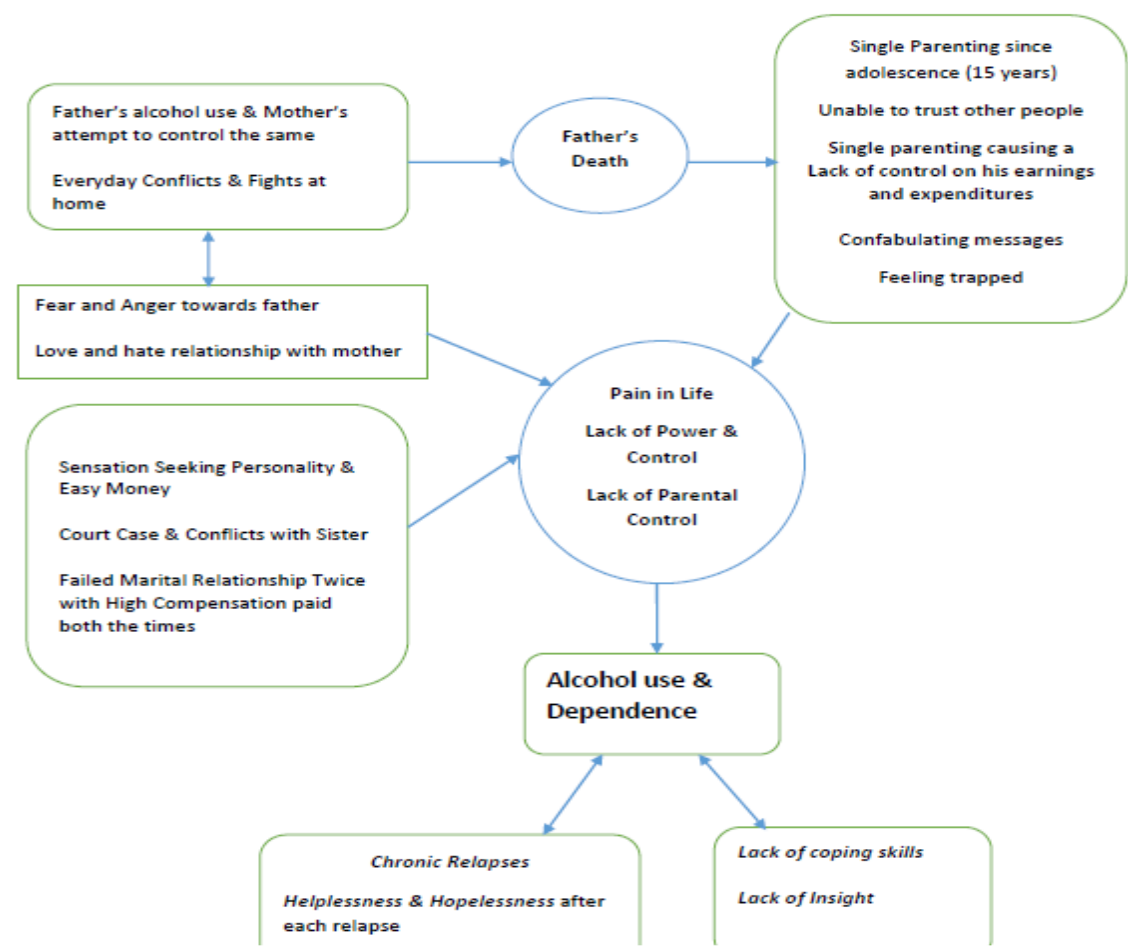

Figure 4-Qualitative Analysis of Patient E

\section{$\underline{\text { Patient E }}$}

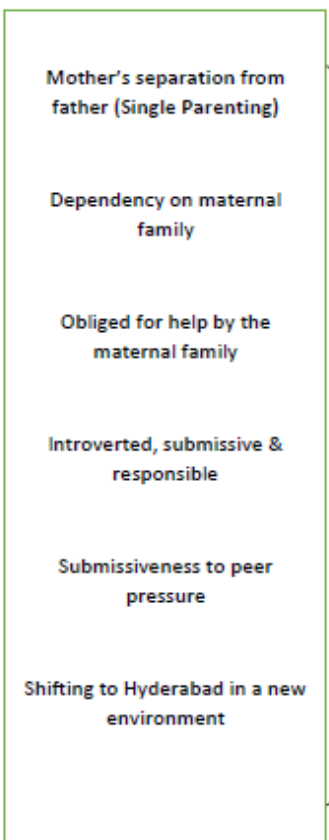

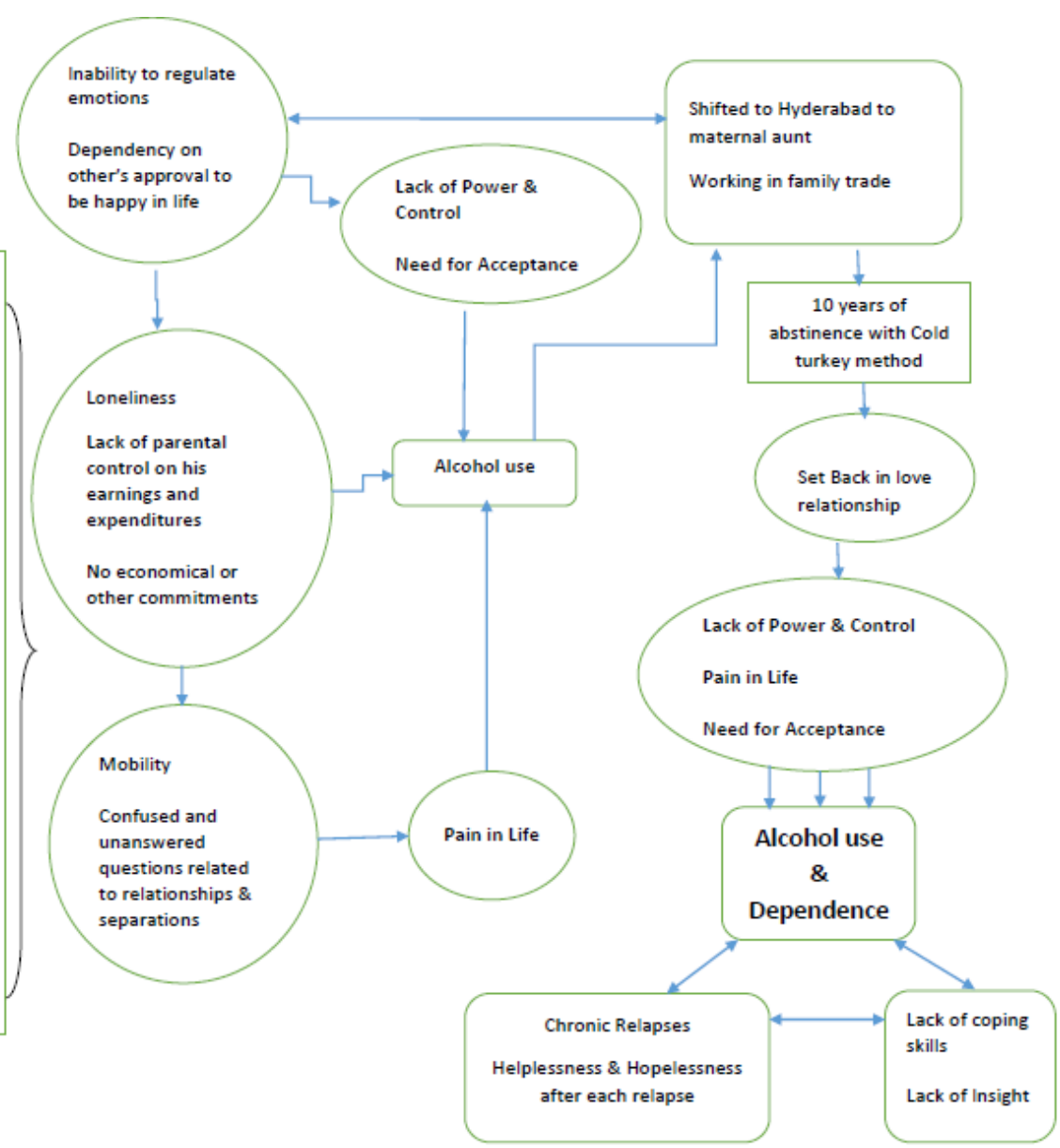

Indian Journal of Mental Health 2017;4(2) 


\section{DISCUSSION}

This paper highlights the profile and pattern of family subsystems functioning which contributes to the child/adolescent substance abuse. Along with the psychosocial factors, emotional factors are also discussed here which gives a more realistic holistic picture. Concept Mapping clearly demonstrates a positive association between single parent family and substance use among adolescents. Case B is worth pointing out as the addiction to drugs began much before the death of mother. Child's temperamental traits (impulsivity, risk taking behavior etc), along with permissive parenting, lack of parental control \& peer pressure marked the onset of polysubstance addiction in the patient. Rest all other cases had a long standing history of marital disharmony before the actual divorce. In accordance to the General Systems Theory we clearly notice the spillover of negative emotions from parental subsystem \& external paternal/maternal family subsystem onto the parent-child \& sibling subsystem. Passing on of confabulating messages, separation anxiety, insecurity \& adjustment problems in the children is clearly evident. As discussed in literature [13-15], exposure to ACEs conveyed a feeling of poor protection by family \& poor social support system which further increased the anxiety \& insecurity in our patients. With divorce or separation the single parent family in our cases had to undergo financial and other resource scarcity which supports the fact highlighted by Williams [50] stating that a great deal of stress is inherent to relationship dissolution. An inability of the child/adolescent to support his family financially caused shame within him which marks poor coping skills. Whatever may be the primary factors, all ultimately led to emotional pain along with lack of power \& control in the subjects. This coupled with the biologically proven fact of substance use causing temporary relief from emotional upsets in humans is the reason why adolescents choose the slippery slope of substance addiction.

As pointed out earlier by researchers [64-65], lack of coping skills \& repeated failures or situational helplessness from chronic stressors was the reason seen for the never stopping vicious circle of addiction in our cases. In accordance with the literature data [66-70] we found our patient's attempting hard enough to avoid drinking, but always landing up drinking more which caused them more shame than before $\&$ thus the vicious cycle of addiction kept on repeating. Here it can be hypothesized that the occurrence of ACEs contributes to the adoption of maladaptive psychological and behavioral coping mechanisms, which makes that individual vulnerable to unhealthy behaviors such as substance abuse. As we hypothesized in the beginning, remarriage or cohabitation were not seen in any of our cases as in Indian culture they are less accepted. Alcohol and tobacco were the most commonly used substances in the above cases which can be easily understood by the fact that these two substances are not included under the NDPS Act of India \& are freely available for use throughout the country. All our patients were males supporting the fact that substance addiction is more common in males in our country. But not even a single female patient may be because of the small sample size of our study population.

\section{CONCLUSION}

Early screening of children/adolescents from broken families is critical for early and effective intervention. Families reporting marital disharmony \& risky substance use behaviors in parents may benefit from intervention services related to interpersonal counseling, motivational interviewing for substance use and teaching of positive parenting behaviors. Administrative \& healthcare systems along with the policy makers could benefit from detailed tracking of children/adolescents in broken homes or single parent family for developing future programs \& good clinical practice guidelines. This will also help them build protective measures \& the possible approaches to evaluate those substance misuse preventive interventions.

There is a clear need to promote preventive \& various harm reduction strategies across the younger age groups residing in high risk families having marital problems or single parent as guardian. Professionals in contact with children from such families should be aware of the various evidence-based interventions and the healthcare professionals' dealing with treatment for substance use disorders in the community. 
These findings indicate that the family structure, interpersonal adjustment, parental supervision, parent child interactions and parental attitude styles need to be assessed in the risk groups to determine substance use risk among children and thus to structure appropriate protective measures.

\section{REFERENCES}

1. Banovcinova A, Levicka J, Veres M. The impact of poverty on the family system functioning. Proc Soc Behav Sci 2014;132:148-53.

2. Von Bertalanffy L. An outline of General System Theory. Br J Philos Sci 1950;1:134-65.

3. Von Bertalanffy L. General systems theory. Open Press : New York ; 1968.

4. Von Bertalanffy L. General theory of systems: Application to psychology. Essays Semiot 1971;4:191-9.

5. Boss P. Family Stress Management: A contextual approach. London: Sage ; 2002.

6. Feinberg ME, Jones DE, Hostetler ML, Roettger ME, Paul IM, Ehrenthal DB. Couple-Focused Prevention at the Transition to Parenthood, a Randomized Trial: Effects on Coparenting, Parenting, Family Violence, and Parent and Child Adjustment. Prev Sci 2016;17(6):751-64.

7. Durtschi JA, Soloski KL, Kimmes J. The Dyadic Effects of Supportive Coparenting and Parental Stress on Relationship Quality Across the Transition to Parenthood. J Marital Fam Ther 2017;43(2):308-21.

8. Feinberg ME. The internal structure and ecological context of coparenting: A framework for research and intervention. Parenting Sci Pract 2003;3:95-131.

9. CBS: Centraal Bureau Statistiek (2010). De Nederlandse samenleving 2010. [The Dutch society 2010]. Retrieved from the internet December 20, 2010.

10. White JM, Klein DM. Family Theories. London: Sage Publications, Inc ; 2008.

11. Bronfenbrenner U. The Ecology of Human Development: Experiments by Nature and Design. Cambridge, MA: Harvard University Press ; 1979.

12. Thompson RG, Lizardi D, Keyes KM, Hasin DS. Childhood or adolescent parental divorce/separation, parental history of alcohol problems, and offspring lifetime alcohol dependence. Drug Alcohol Depend 2008;98(3):264-9.

13. Jackson KM, Rogers ML, Sartor CE. Parental divorce and initiation of alcohol use in early adolescence. Psychol Addict Behav 2016;30(4):450-61.

14. Gauffin K, Hjern A, Vinnerljung B, Björkenstam E. Childhood Household Dysfunction, Social Inequality and Alcohol Related Illness in Young Adulthood. A Swedish National Cohort Study. PLoS One 2016;11(3):e0151755.

15. Thomas JR, Högnäs RS. The Effect of Parental Divorce on the Health of Adult Children. Longit Life Course Stud 2015;6(3):279-302.

16. American Academy of Pediatrics. Family Pediatrics: Report of the task force on the family. Pediatrics 2003;111:1541-71.

17. Sameroff A. A unified theory of development: A dialectic integration of nature and nurture. Child Dev 2010;81:6-22.

18. Cowan PA, Cohn DA, Cowan CP, Pearson JL. Parents' attachment histories and children's externalizing and internalizing behaviors: Exploring family systems models of linkage. J Consult Clin Psychol 1996;64:5363.

19. Golombok S. Parenting: What really counts? London: Routledge; 2002.

20. Erel O, Burman B. Interrelatedness of marital relations and parent-child relations: A meta-analytic review, Psychol Bull 1995;118:108-32.

21. Amato PR, Afifi TD. Feeling caught between parents: Adult children's relations with parents and subjective well-being. J Marr Family 1998;68:222-35.

22. Hakvoort EM, Bos HM, van Balen F, Hermanns JM. Family relationships and the psychosocial adjustment of school-aged children in intact families. J Genet Psychol 2010;171(2):182-201

23. Snyder J, Bank L, Burraston B. The consequences of antisocial behavior in older male siblings for younger brothers and sisters. J Fam Psychol 2005;19:643-53.

24. Wilkinson RB. The role of parental and peer attachment in the psychological health and self-esteem of adolescents. J Youth Adolesc 2004;33:479-93.

25. Bowlby J. A Secure Base: Parent-Child Attachment and Healthy Human Development. New York: Basic Books; 2008. 
26. Padilla-Walker LM, Nelson LJ, Madsen SD, Barry CM. The role of perceived parental knowledge on emerging adults' risk behaviors. J Youth Adolesc 2008;37:847-59.

27. Repetti RL, Taylor SE, Seeman TE. Risky families: family social environments and the mental and physical health of offspring. Psychol Bull 2002;128:330-52.

28. Fosco GM, Stormshak EA, Dishion TJ, Winter CE, Fosco GM, Stormshak EA. Family Relationships and Parental Monitoring During Middle School as Predictors of Early Adolescent Problem Behavior. J Clin Child Adolesc Psychol 2012;41:202-12.

29. Van Petegem S, Beyers W, Vansteenkiste M, Soenens B. On the association between adolescent autonomy and psychosocial functioning: examining decisional independence from a self determination theory perspective. Dev Psychol 2012;48:76-89.

30. McCann M, Perra O, McLaughlin A, McCartan C,Higgins K. Assessing elements of a family approach to reduce adolescent drinking frequency: parent-adolescent relationship, knowledge management and keeping secrets. Addiction 2016;111(5):843-53.

31. Kepple NJ. The Complex Nature of Parental Substance Use: Examining Past Year and Prior Use Behaviors as Correlates of Child Maltreatment Frequency. Substance Use Misuse 2017;52(6):811-21.

32. Hakvoort E. Parenting and child adjustment after divorce: family relationship quality, parental stress, and child adjustment in post-divorce families. FMG: Research Institute Child Development and Education (CDE); 2011.

33. Amato PR, Keith B. Parental divorce and the well-being of children: A meta-analysis. Psychol Bull 1991;110:26-46.

34. Amato P. Children of divorce in the 1990s: An update of the Amato and Keith (1991) meta-analysis. J Fam Psychol 1999; 15:355-70.

35. Horowitz, M, Schaefer C, Hiroto D, Wilner N, Levin B. Life Event Questionnaires for Measuring Presumptive Stress. Psychosom Med 1977;39:413-31.

36. Holmes TH, Rahe RH. The social readjustment rating scale. J Psychosom Res 1967;11:213-8.

37. Bouman AM. Statistics Netherlands. Retrieved on 6 October, 2009 from: http://www.cbs.nl/nlNL/menu/themas/bevolking/publicaties/artikelen/ archief/ 2004/ 2004-1461-wm.htm

38. Raymo JM, Park H, Iwasawa M, Zhou Y. Single Motherhood, Living Arrangements, and Time With Children in Japan. Fam Relat, 2004;76:843-61.

39. Golombok S. Parenting: What really counts? London: Routledge ; 2000.

40. Thompson MS, Ensminger ME. Psychological Well-Being Among Mothers With School Age Children: Evolving Family Structures. Social Forces 1989;67(3):715-30.

41. Ang RP. Dysfunctional parenting behaviors and parenting stress among mothers of aggressive boys. Child Fam Behav Ther 2008;30:319-36.

42. Bornstein MH. Handbook of Parenting, Second Edition: Volume 4: Social Conditions and Applied Parenting, Mahwah, NJ: Lawrence Erlbaum Associates ; 2002.

43. Helms-Erickson H. Marital quality ten years after the transition to parenthood: Effects of the timing of parenthood and the division of housework. J Marriage Fam 2001;63:1099-110.

44. Raymo JM. Single Motherhood and Children's Health and School Performance in Japan. Marriage Fam Rev 2016;52(1-2);64-88.

45. Kitson GC. Divorce and Relationship Dissolution Research: Then and Now. In MA Fine, JH Harvey (Eds.), Handbook of Divorce and Relationship Dissolution (pp. 15-40). NY: Routledge Taylor \& Francis Group ; 2006.

46. Schaan VK, Vogele C. Resilience and rejection sensitivity mediate long-term outcomes of parental divorce. Eur Child Adolesc Psychiatry 2016;25(11):1267-9.

47. Fombonne E. Increased rates of psychosocial disorders in youth. Eur Arch Psychiatr Clin Neurosci 1998;248:14-21.

48. Maughan B, Iervolino A, Collishaw S. Time trends in child and adolescent mental disorders. Curr Opin Psychiatry 2005; 18:381-5.

49. Rutter M, Smith DJ. Psychosocial disorders in young people: Time trends and their causes. Chichester: Wiley; 1995.

50. Canetti L, Bachar E, Bonne O, Agid O, Lerer B, De-Nour AK, and Shalev AY. The Impact of Parental Death Versus Separation From Parents on the Mental Health of Israeli Adolescents. Compr Psychiatry 2000;41(5):360-8.

51. Williams K, Umberson D. Marital Status, Marital Transitions, and Health: A Gendered Life Course Perspective. J Health Soc Behav 2004;45:81-98.

52. Felitti VJ. The relation between adverse childhood experiences and adult health: Turning gold into lead. Perm J. 2002;6(1):44-7. 
53. Bellis MA, Lowey H, Leckenby N, Hughes K, Harrison D. Adverse childhood experiences: retrospective study to determine their impact on adult health behaviours and health outcomes in a UK population. J Pub Health 2014;36:81-91

54. Ehlert U. Enduring psychobiological effects of childhood adversity. Psychoneoroendocrinology 2009;38:1850-7.

55. Douglas KR, Chan G, Gelernter J, Arias AJ, Anton RF, Weiss RD, Brady K, Poling J, Farrer L, Kranzler HR. Adverse childhood events as risk factors for substance dependence: partial mediation by mood and anxiety disorders. Addict Behav 2010;35(1):7-13.

56. Anda RF, Whitfield CL, Felitti VJ, Chapman D, Edwards VJ, Dube SR, Williamson DF. Adverse childhood experiences, alcoholic parents, and later risk of alcoholism and depression. Psychiatr Serv 2002;53(8):1001-9.

57. Hill NE, Bromell L, Tyson DF, Flint R. Developmental commentary: Ecological perspectives on parental influences during adolescence. J Clin Child Adolesc Psychol 2007;36:367-77.

58. Bernet W, Wamboldt MZ, Narrow WE. Child Affected by Parental Relationship Distress. J Am Acad Child Adolesc Psychiatry 2016;55(7):571-9.

59. McEwen BS, Eiland L, Hunter RG, Miller MM. Stress and anxiety: structural plasticity and epigenetic regulation as a consequence of stress. Neuropharmacology 2012;62(1):3-12.

60. Danese A, McEwen BS. Adverse childhood experiences, allostasis, allostatic load, and age-related disease. Physiol Behav 2012;106(1):29-39.

61. Toyokawa S, Uddin M, Koenen KC, Galea S. How does the social environment 'get into the mind'? Epigenetics at the intersection of social and psychiatric epidemiology. Soc Sci Med 2012; 74(1):67-74.

62. Dube SR, Felitti VJ, Dong M, Chapman DP, Giles WH, Anda RF. Childhood abuse, neglect, and household dysfunction and the risk of illicit drug use: the adverse childhood experiences study. Pediatrics 2003;111(3):564-72.

63. Dube SR, Anda RF, Felitti VJ, Edwards VJ, Croft JB. Adverse childhood experiences and personal alcohol abuse as an adult. Addict Behav 2002;27(5):713-25.

64. Mclaughlin KA, Conron KJ, Koenen KC, Gilman SE. Childhood adversity, adult stressful life events, and risk of past-year psychiatric disorder: a test of the stress sensitization hypothesis in a population-based sample of adults. Psychol Med 2010;40(10):1647-58.

65. Schüssler-Fiorenza Rose SM, Xie D, Stineman M .Adverse childhood experiences and disability in U.S. adults. Prev Med Res 2014;6(8):670-80.

66. Fossum MA, Mason M. Facing shame: Families in recovery. New York: W.W. Norton \& Co; 1986.

67. Bradshaw J. Healing the shame that binds you. Deerfield Beach, Fla: Health Communications; 1988.

68. Potter-Efron RT. Shame, guilt, and alcoholism: Treatment issues in clinical practice. New York: Haworth Press; 1989.

69. Potter-Efron R. Shame, guilt, and alcoholism. New York: Haworth Press; 2002.

70. Wiechelt SA. The specter of shame in substance misuse. Subst Use Misuse 2007;42:399-409.

71. Dishion TJ, Nelson SE, Kavanagh K. The Family Check-Up with high-risk young adolescents: Preventing early-onset substance use by parent monitoring. Behav Ther 2003;34:553-71.

72. Afifi TO, Henriksen CA, Asmundson GJ, Sareen J. Childhood maltreatment and substance use disorders among men and women in a nationally representative sample. Can J Psychiatry 2012; 57:677-86.

73. Dube SR, Miller JW, Brown DW, Giles WH, Felitti VJ, Dong M. Adverse childhood experiences and the association with ever using alcohol and initiating alcohol use during adolescence. J Adolesc Health 2006;38:444,e1-10.

74. Fuller-Thomson E, Filippelli J, Lue-Crisostomo CA. Gender-specific association between childhood adversities and smoking in adulthood: findings from a population-based study. Public Health 2013;127:44960 .

75. Madruga CS, Laranjeira R, Caetano R, Ribeiro W, Zaleski M, Pinsky I. Early life exposure to violence and substance misuse in adulthood - the first Brazilian national survey. Addict Behav 2011;36:251-5.

76. Ford ES, Anda RF, Edwards VJ, Perry GS, Zhao G, Li C. Adverse childhood experiences and smoking status in five states. Prev Med 2011;53:188-93.

77. Felitti VJ, Anda RF, Nordenberg D, Williamson DF, Spitz AM, Edwards V. Relationship of childhood abuse and household dysfunction to many of the leading causes of death in adults. The Adverse Childhood Experiences (ACE) Study. Am J Prev Med 1998;14:245-58.

78. World Health Organization. Adverse Childhood Experiences International Questionnaire (ACE-IQ).

79. Madruga CS, Laranjeira R, Caetano R, Pinsky I, Zaleski M, Ferri CP. Use of licit and illicit substances among adolescents in Brazil: a national survey. Addict Behav 2012;37:1171-5. 
80. Schwandt ML, Heilig M, Hommer DW, George DT, Ramchandani VA. Childhood trauma exposure and alcohol dependence severity in adulthood: mediation by emotional abuse severity and neuroticism. Alcohol Clin Exp Res 2013;37:984-92.

81. Sitnick SL, Shaw DS, Hyde LW. Precursors of adolescent substance use from early childhood and early adolescence: testing a developmental cascade model. Dev Psychopathol 2014;26:125-40.

82. Lopes GM, Nobrega BA, Del Prette G, Scivoletto S. Use of psychoactive substances by adolescents: current panorama. Rev Bras Psiquiatr 2013;35(Suppl 1):S51-61.

83. Sindelar HA, Barnett NP, Spirito A. Adolescent alcohol use and injury: a summary and critical review of the literature. Minerva Pediatr 2004;56:291-309.

84. Amato PR. The impact of divorce on men and women in India and the United States. J Comp Fam Stud 1994;1:207-21.

85. Ahmad I. Divorce and remarriage among Muslims in India. Manohar Publishers; 2003.

86. Pothen S. Divorce: Its causes and consequences in Hindu society. Vikas Publishers; 1986.

87. Bare Act. New Delhi: Professional Book Publishers; 2002. The Hindu Marriage Act, 1955. As Amended by Marriage Laws (Amendment Act, 2001) (49 of 2001) with State Amendments.

88. Sundar R, Acharya P, Mookharjee D, Babar M, Ravikumar U, Vashisht C, Badol A. A Study of single mothers in 4 metro cities of India. An Initiative by Ministry of Women and Child Development. Conducted by Partners in Development Initiatives Year: 2011.

89. Amato PR, Anthony CJ. Estimating the Effects of Parental Divorce and Death With Fixed Effects Models. J Marriage Fam 2014;76(2):370-86.

90. Tyrka AR, Wier L, Price LH, Ross N, Anderson GM, Wilkinson CW, Carpenter LL. Childhood parental loss and adult hypothalamic-pituitary-adrenal function. Biol Psychiatry 2008;63(12):1147-54.

91. Bratek A , Beil J , Banach M, Jarzabek K \& Krysta K. The Impact of family environment on the development of alcohol dependence. Psychiatr Danub 2013;25(2):74-7.

92. Reddy KR, Biswas A. Substance abuse in urban school going adolescents in India: A growing challenge. Indian Pediatr 2013;50:799-800.

93. Pal H, Srivastava A, Dwivedi SN, Pandey A and Nath J. Prevalence of Drug Abuse in India through a National Household Survey. Int J Curr Sci 2015;15:e103-13.

94. International Labour Organization. Report VI. Child Labour: Targeting the Intolerable. International Labour Organization c1996. [Monograph on the Internet]. International Labour Organization. 2001.

95. Bloom BS. Taxonomy of educational objectives; the classification of educational goals (1st ed.). New York: Longmans Green ; 1956.

96. Edmondson K. Assessing science understanding through concept maps. In J. Mintzes, J. Wandersee \& J. Novak (Eds.), Assessing science understanding (pp. 19-40). San Diego: Academic Press ; 2000.

97. Ford KM, Cañas AJ, Jones J, Stahl H, Novak JD, Adams-Webber J. Iconkat: An integrated constructivist knowledge acquisition tool. Knowledge Acquisition 1991;3:215-36.

98. Ford KM, Coffey JW, Cañas AJ, Andrews EJ, Turner CW. Diagnosis and explanation by a nuclear cardiology expert system. Int J Expert Syst 1996;9:499-506.

99. Novak JD. Concept maps and vee diagrams: Two metacognitive tools to facilitate meaningful learning. Instruct Sci 1999;19:29-52.

100.Novak JD, Cañas AJ. The Theory Underlying Concept Maps and How to Construct Them, Technical Report IHMC ; 2008.

101.Heinze-Fry JA, Novak JD. Concept mapping brings long-term movement toward meaningful learning. Science Education 1990;74:461-72.

102.Novak JD. Learning, creating, and using knowledge: Concept maps as facilitative tools in schools and corporations. Mahwah, NJ: Lawrence Erlbaum Associates, Inc. ; 1998

103.Bowling A. Research Methods in Health: Investigating Health and Health Services. Philadelphia: Open University Press; 2002.

$$
\begin{aligned}
& \text { Acknowledgements - Nil } \\
& \text { Source of Funding - Nil } \\
& \text { Conflict of Interest - Nil }
\end{aligned}
$$

